\title{
Genetic Improvement of Beach Strawberry
}

\author{
J.F. Hancock, C.A. Drake, and P.W. Callow \\ Department of Horticulture, Michigan State University, East Lansing, Michigan 48824 \\ S. Serçe \\ Department of Horticulture, Mustafa Kemal University, Antakya, Hatay, Turkey 31034
}

The commercial strawberry, $F$. ×ananassa, originated about 250 years ago when a few New World clones of $F$. chiloensis and F. virginiana accidentally hybridized in European gardens (Wilhelm and Sagen, 1972). Thomas A. Knight began the systematic breeding of strawberries in England in 1817, but had at his disposal only a small number of native and cultivated clones. Likewise, NorthAmerican genetic improvement began in the mid-1800s with a restricted group of European $F$. ×ananassa cultivars, South American $F$. chiloensis and North American F. virginiana (Darrow, 1966). The cultivars originating from this background played the predominant role in most public and private breeding programs for the next 100 years.

Most genes in modern cultivars still come from a very limited number of genotypes, even though at least eight native clones have been incorporated into cultivars in the last half century (Dale and Sjulin, 1990; Hancock and Luby, 1995; Sjulin and Dale, 1987). Since the germplasm base of strawberries remains so narrow, it seems likely that numerous genes of horticultural benefit have been missed in the native germplasm. To rectify this situation, a number of North American strawberry breeders are working together to expand the strawberry germplasm base including Adam Dale(University of Guelph, Ontario), ChadFinn (USDA-ARS, Oregon), Jim Hancock (Michigan State University) and Jim Luby (University of Minnesota). Our primary goals are to: 1) Identify native clones with horticulturally useful genes, 2) Expand the germplasm base of $F$. $\times$ ananassa by hybridizing it with elite native octoploid clones, 3 ) Reconstruct $F$. $\times$ ananassa using elite wild octoploid clones, and 4) Develop a supercore collection of wild $F$. chiloensis and $F$. virginiana that can be used by other breeders. This work has been described elsewhere and will not be further addressed here (Hancock et al., 2000, 2001, 2003; Luby et al., 1991).

We are also interested in breeding cultivars of pure $F$. chiloensis, and this effort will be the focus of this report. Fragaria chiloensis is found naturally in a narrow coastal band from central California to Alaska in North America, and along the coast and well into the mountains of central Chile. The Mapuche Indians of Chile domesticated F. chiloensis over 1000 years ago, and produced a number of superior clones with large fruit size, high soluble solids and marvelous aromatics (Finn et al., 1998; Hancock et al., 2000; Lavín, 2000). These landraces were grown widely in Chile, Peru and Ecuador until higher yielding, red-fruited cultivars of $F . \times$ ananassa arrived from Europe in the 1950s. The North American types of $F$. chiloensis were never domesticated and they have smaller fruit than their South American counterparts, but they are in general better colored and produce more flowers. It is our goal to combine the large fruit size of the South American land races of $F$. chiloensis, with the high numbers and deep color of the northern types.

The time is long overdue to breed pure cultivars of $F$. chiloensis. The ancient cultivated types are still being grown in small acreages in Chile and Ecuador, and recent studies have shown that improved native genotypes could be an extremely popular and profitable (Lavín and Maureira, 2000). In our recent germplasm collection trip to Ecuador, we were told by many individuals that they fondly remembered the old F. chiloensis cultivars and were willing to pay a premium price for their fruit. Considerable interest has also grown in Japan (T. Nishizawa, personal communication), and we expectastrong niche market could be developed in the U.S.

\section{Materials and Methods}

We crossed four Chilean landraces with superior combinations of high soluble solids, excellentflavor, strong aroma, large size butpoor color and low yields [2BRA 1A and CFRA 24 (Chile)CFRA372 (Peru) and NAH-5 (Ecuador)] with several native clones with either high fruit numbers [HM1 (Oregon) and MAR 2B (Chile)], unusually large fruit size and dark internal color [Scotts Creek (California)] or multiple disease resistance [RCP-37 (California)] (Cameron et al., 1993; Hancock et al., 2000). HM1, NAH-
5 and Scotts Creek were hybridized as male parents with 2BRA 1A, CFRA 24, CFRA 372, MAR 2B and RCP-37.

Twenty to fifty representatives of each family were planted in June 2000 in a commercial potting mix in $4 \times 4 \times 4$-cm pots and set in a randomized complete block design in a greenhouse at MSU (two replications of each family). Runners were removed on a weekly basis in the first growing season. In March 2001, the number of crowns produced by each mother plant was determined. When flowering began in April, a camel hairbrush was used to mix pollen from all open flowers in the greenhouse on a 3- to 4-d sequence. The date of each genotypes first flower was recorded and at the conclusion of anthesis, the number of flowers per plant were counted, along with the length of the longest inflorescence. The date of each genotypes first ripe fruit was recorded, and the first three ripe fruit of each genotype were weighed and the skin and flesh color of each was evaluated on a scale of 1 to 10 (white to deep red). The total number of runners produced by each plant in the second growing season was recorded in August. The full sib families were analyzed as a factorial design to calculate general and specific combining ability (GCA and SCA) (Comstock and Robinson, 1948). Analyses of variance tables were produced using the SAS GLM procedure (SAS, 1990).

To get an indication of which parental combinations were the most superior, the progeny means for each cross were given a rank of 1 to 5 for crown number, runner number, fruit weight, peduncle length and fruit color (mean of skin and flesh color scores). The 15 families were ranked for each trait and divided into 5 groups of triplets. The families with the lowest values were scored as 1 , while the families with the highest numbers were scored as 5 . The values from the five traits were then summed to calculate an overall performance score.

\section{Results and Discussion}

GCAwas significantforall traits exceptcrown

Table 1. Analysis of variance and percent variance in each component (in parenthesis) for several horticulturally important traits in full-sib families of Fragaria chiloensis grown in a greenhouse in East Lansing, Mich.

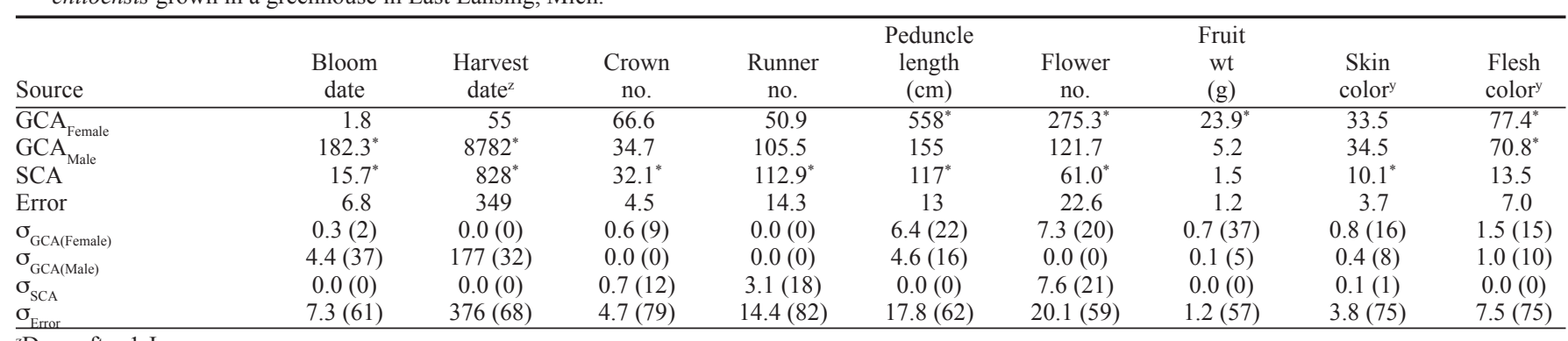

${ }^{2}$ Days after 1 Jan.

${ }^{\mathrm{y}} 1$ to 10 scale $(1=$ white and $10=$ dark red $)$

*Significant at $p<0.05$. 
Table 2. Mean values for several horticulturally important traits in full-sib families from Fragaria chiloensis crosses grown in a greenhouse in East Lansing, Mich.

\begin{tabular}{|c|c|c|c|c|c|c|c|c|c|}
\hline Source & $\begin{array}{c}\text { Bloom } \\
\text { date }\end{array}$ & $\begin{array}{c}\text { Harvest } \\
\text { date }^{z}\end{array}$ & $\begin{array}{c}\text { Crown } \\
\text { no. }\end{array}$ & $\begin{array}{c}\text { Runner } \\
\text { no. }\end{array}$ & $\begin{array}{l}\text { Peduncle } \\
\text { length } \\
(\mathrm{cm})\end{array}$ & $\begin{array}{c}\text { Flower } \\
\text { no. }\end{array}$ & $\begin{array}{c}\text { Fruit } \\
\text { wt } \\
(\mathrm{g})\end{array}$ & $\begin{array}{l}\text { Skin } \\
\text { color }^{y}\end{array}$ & $\begin{array}{l}\text { Flesh } \\
\text { color }\end{array}$ \\
\hline \multicolumn{10}{|l|}{ Female } \\
\hline HM1 & 5.5 & 117 & 4.3 & 3.5 & 6.2 & 9.7 & 1.4 & 4.8 & 4.7 \\
\hline $\mathrm{NAH}$ & 5.8 & 112 & 2.3 & 3.5 & 11.7 & 4.9 & 3.1 & 3.6 & 3.1 \\
\hline Scotts Creek & 4.6 & 112 & 3.1 & 4.4 & 5.6 & 5.1 & 2.2 & 5.7 & 5.8 \\
\hline \multicolumn{10}{|l|}{ Male } \\
\hline 2BRA 1A & 8.1 & 138 & 3.0 & 4.4 & 10.1 & 4.9 & 2.0 & 5.3 & 5.3 \\
\hline CFRA 24 & 3.6 & 106 & 2.9 & 3.6 & 6.3 & 8.1 & 2.3 & 4.4 & 4.0 \\
\hline CFRA 372 & 4.1 & 106 & 3.6 & 1.1 & 9.1 & 7.5 & 2.7 & 3.7 & 3.3 \\
\hline MAR 2B & 7.7 & 134 & 3.6 & 4.7 & 9.8 & 3.9 & 2.1 & 5.5 & 6.8 \\
\hline RCP 37 & 5.4 & 116 & 3.4 & 4.1 & 5.2 & 8.2 & 1.5 & 5.5 & 5.5 \\
\hline Mean & 5.3 & 114 & 3.2 & 3.9 & 7.1 & 7.2 & 2.1 & 4.7 & 4.6 \\
\hline Standard error & 0.18 & 1.1 & 0.09 & 0.15 & 0.28 & 0.33 & 0.07 & 0.11 & 0.15 \\
\hline
\end{tabular}

${ }^{2}$ Days after 1 Jan.

y 1 to 10 scale $(1=$ white and $10=$ dark red $)$.

Table 3. Mean trait values and relative rankings (parenthesis) of full-sib families of Fragaria chiloensis crosses grown in a greenhouse in East Lansing, Mich.

The families with the lowest values were scored as 1 , while the families with the highest numbers were scored as 5 (see text for details).

\begin{tabular}{|c|c|c|c|c|c|c|c|c|c|}
\hline Female & Male & $\begin{array}{c}\text { Bloom } \\
\text { date }\end{array}$ & $\begin{array}{c}\text { Harvest } \\
\text { date }\end{array}$ & $\begin{array}{c}\text { Crown } \\
\text { no. }\end{array}$ & $\begin{array}{c}\text { Runner } \\
\text { no. }\end{array}$ & $\begin{array}{c}\text { Flower } \\
\text { no. }\end{array}$ & $\begin{array}{c}\text { Fruit } \\
\text { wt (g) }\end{array}$ & $\begin{array}{l}\text { Fruit } \\
\text { color }^{\mathrm{y}}\end{array}$ & $\begin{array}{c}\text { Overall } \\
\text { performance }^{\mathrm{w}}\end{array}$ \\
\hline HM1 & 2BRA 1A & $7.6(4)$ & $135.2(5)$ & $4.7(5)$ & $4.3(5)$ & $7.6(4)$ & $1.5(2)$ & $5.6(4)$ & 19 \\
\hline HM1 & CFRA 24 & $4.1(2)$ & $110.2(2)$ & $4.2(4)$ & $2.4(2)$ & $4.1(2)$ & $1.5(2)$ & $4.1(2)$ & 12 \\
\hline HM1 & CFRA 372 & $4.3(2)$ & $101.3(1)$ & $1.3(1)$ & $0.3(1)$ & $4.3(3)$ & $1.5(2)$ & $2.7(1)$ & 8 \\
\hline HM1 & MAR 2B & $6.3(4)$ & $123.4(4)$ & $5.5(5)$ & $4.0(3)$ & $6.3(4)$ & $0.8(1)$ & $6.9(4)$ & 17 \\
\hline HM1 & RCP 37 & $5.6(3)$ & $120.9(3)$ & $3.9(4)$ & $4.1(4)$ & $5.6(3)$ & $1.2(1)$ & $5.5(3)$ & 15 \\
\hline $\mathrm{NAH}$ & $2 \mathrm{BRA} 1 \mathrm{~A}$ & $9.7(5)$ & $144.2(5)$ & $2.6(3)$ & $2.6(2)$ & $9.7(5)$ & $3.0(5)$ & $4.1(2)$ & 17 \\
\hline NAH & CFRA 24 & 3.1 (1) & 100.1 (1) & $1.5(1)$ & $2.5(2)$ & 3.1 (1) & $3.2(5)$ & $3.0(1)$ & 10 \\
\hline NAH & CFRA 372 & $3.9(2)$ & $103.3(1)$ & $3.6(3)$ & $0.5(1)$ & $3.9(2)$ & $3.1(5)$ & $2.9(1)$ & 12 \\
\hline $\mathrm{NAH}$ & MAR 2B & $8.7(5)$ & $134.2(4)$ & $2.1(1)$ & $6.0(5)$ & $8.7(5)$ & $3.0(4)$ & $4.5(2)$ & 17 \\
\hline NAH & RCP 37 & 3.0 (1) & $121.0(3)$ & $2.4(2)$ & $4.8(4)$ & 3.0 (1) & $2.0(4)$ & $7.0(5)$ & 16 \\
\hline Scotts Creek & 2BRA $1 \mathrm{~A}$ & $5.8(4)$ & $125.8(4)$ & $2.3(2)$ & $6.6(5)$ & $5.8(4)$ & 1.1 (1) & $8.0(5)$ & 17 \\
\hline Scotts Creek & CFRA 24 & $3.5(1)$ & $105.5(2)$ & $2.4(2)$ & $5.2(5)$ & 3.5 (1) & $2.6(4)$ & $5.5(4)$ & 16 \\
\hline Scotts Creek & CFRA 372 & $4.3(3)$ & $116.4(3)$ & 3.9 (4) & $1.6(1)$ & $4.3(2)$ & $1.9(3)$ & $5.4(3)$ & 13 \\
\hline Scotts Creek & MAR 2B & $7.8(5)$ & $138.5(5)$ & $5.0(5)$ & $3.1(3)$ & $7.8(5)$ & $1.7(3)$ & $7.5(5)$ & 21 \\
\hline Scotts Creek & RCP 37 & $5.1(3)$ & $112.1(2)$ & $3.1(3)$ & $3.9(3)$ & $5.1(3)$ & $1.8(3)$ & $5.4(3)$ & 15 \\
\hline
\end{tabular}

${ }^{\mathrm{z}}$ Days after 1 Jan.

${ }^{y}$ Average of skin and flesh color scores $(1=$ white and $10=$ dark red $)$.

${ }^{\text {w }}$ Sum of the ranking for crown number, runner number, flower number, fruit weight, and fruit color.

and runner number; SCA was significant for all traits except fruit weight and flesh color (Table 1). Much higher GCA was observed for peduncle length, flowernumber, and fruit weight among the female parents, while the males had higher GCA forbloom date and harvest date. This indicates that genotypes used as male parents (HM1, NAH-5, and Scotts Creek) were more variable for bloom and harvest dates than genotypes used as females (2BRA 1A, CFRA 24, CFRA 372, MAR 2B, and RCP 37), and that female parents were more variable for peduncle length, flower number, and fruit weight than male parents.

Progeny means varied significantly for all the evaluated traits (Table 2). NAH-5 and CFRA 372 transmitted the largest fruit size. HM1 produced progeny with the most crowns and highest flower numbers, while the progeny of MAR 2B had the most runners. Scotts Creek, RCP 37, and MAR 2B were the best parents for fruit color. Progeny of MAR 2B and BRA 1A were the latest fruiting, while those of CFRA 24 and CFRA 372 were the earliest.

In the comparison of overall performance, the cross Scotts Creek $\times$ MAR 2B yielded progeny with the highest overall score (21), followed by HM1 $\times 2$ BRA 1 A (19), HM $1 \times$ MAR 2B (17), NAH-5 $\times$ 2BRA 1A (17), NAH-5 $\times$ MAR 2B (17), Scotts Creek $\times$ 2BRA 1A (17), and Scotts Creek $\times$ CFRA 24 (16) (Table 3). Most notable among this group were several late flowering and fruiting types: 1) Scotts Creek $\times$ MAR 2B with many well colored, average sized fruits and high crown numbers, 2) NAH $\times$ 2BRA $1 \mathrm{~A}$ with many pale, large fruit and average crown numbers, and 3) NAH $\times$ MAR $2 \mathrm{~B}$ with many pale, large fruit and high runner numbers. Among the early ripening families, Scotts Creek $\times$ CFRA 24 was most superior with large well-colored fruit and high runner numbers, but low flower numbers.

\section{Overall Conclusions}

Breeding within F. chiloensis should result in rapid genetic improvement. It was relatively easy to combine large fruit size with high yield potential, either through high crown production (hill culture types) or runner production (matted row types). Considerable variation was also observed for fruit color and harvest season, indicating it is possible to develop both red and white fruited varieties with a wide range in flowering and fruiting times.

\section{Literature Cited}

Cameron, J.S., T.M. Sjulin, J.R. Ballington, C.H. Shanks, C.E. Munoz, and A. Lavín. 1993. Exploration, collection and evaluation of Chilean Fragaria: Summary of 1990 and 1992 expeditions. Acta Hort. 348:65-74.

Comstock, K.R.E. and H.F. Robinson. 1948. The components of genetic variance in populations of biparental progenies and their use in estimating the average degree of dominance. Biometrics 4:254-266.

Dale, A. and T.M. Sjulin. 1990. Few cytoplasms contribute to North American strawberry cultivars. HortScience
$25 \cdot 1341-1342$

Darrow, G.M. 1966. The strawberry. History, breeding and physiology. Holt, Rinehart and Winston, New York.

Finn, C., J. Hancock, and C. Heider. 1998. Notes on the strawberry of Ecuador: Ancient land races, the community of farmers and modern production. HortScience 33:583-587.

Hancock, J.F., P.W. Callow, A. Dale, J.J. Luby, C.E. Finn, S.C. Hokanson, and K. Hummer. 2000. From the Andes to the Rockies: Native strawberry collection and utilization. HortScience 36:221-224

Hancock, J.F., C.E. Finn, S.C. Hokanson, J.J. Luby, B.L. Goulart, K. Demchak, P.W. Callow, S. Serçe, A.M.C. Schilder, and K.E. Hummer. 2001. Amultistate comparison of native octoploid strawberries from North and South America. J. Amer. Soc. Hort. Sci. 126:579-588.

Hancock, J.F., P.W. Callow, S. Serçe, and P.Q. Phan. 2003. Variation in the horticultural characteristics of native Fragaria virginiana and $F$. chiloensis from North and South America. J. Amer. Soc. Hort. Sci. 128:201-208.

Hancock, J.F. and J.J. Luby. 1995. Adaptive zones and ancestry of the most important North American strawberry cultivars. Fruit Var. J. 49:85-89.

Lavín, A. 2002. Distribucion actual de Fragaria chiloensis (L.) Duch. En Chile. Plant Genet. Resour. Nwsl. 122:24-28.

Lavín, A. and M. Maureira. 2000. La frutilla Chilena de fruto blanco. Instituto de Investigaciones Agropecuarias, Boletin INIA no. 39

Luby, J.J., J.F. Hancock, and J.S. Cameron. 1991. Expansion of the strawberry germplasm base in North America, $p$. 66-75. In:A. Dale and J.Luby (eds.). The strawberry into the 21 st century. Timber Press, Portland, Ore.

SAS Institute Inc., 1990. SAS users guide; SAS/STAT, version 6. SAS Inst. Inc., Cary, N.C.

Sjulin, T.M. and A. Dale. 1987. Genetic diversity of North American strawberry cultivars. J. Amer. Soc. Hort. Sci. 112:375-385.

Wilhelm, S. and J.A. Sagen 1974. AHistory of the Strawberry. Univ. Calif., Berkeley, Div. Agr. Publ. 4031. 